\title{
PENGUATAN REGULASI DALAM PENCEGAHAN DAN PENANGGULANGAN PERKAWINAN ANAK
}

\author{
Nurnazli* \\ Universitas Islam Negeri (UIN) Raden Intan Lampung \\ Email: nurnazlibukhari1971@gmail.com
}

\begin{abstract}
This article elaborates on solutions to promote and strengthen the regulation preventing child marriage practices in Indonesia, so the purpose of marriage that to create a happy and eternal family will be created based on the One True God. The equality paradigm in determining the minimum age of marriage has been realized by the Indonesian Government by raising Law No. 16 of 2019 on Amendment to Law No 1 of 1974 on Marriage. Article 7 paragraph (1) on the Post Revised Marriage Law explains that the minimum age for a marriage is 19 years and no age difference between spouses (men and women). The purpose of the Act is the Indonesian government can be more serious in minimizing the child marriages that still happen today. This research found that the following steps can strengthen the regulation preventing child marriage. First, create intense communication within the family. Secondly, it involves the judiciary in the context of enforcing rules regarding the age limit of marriage. Third, the Supreme Court must immediately make rules that can complicate marriage dispensation. Fourth, providing socialization related to the rule of law regarding the minimum age for marriage and counseling about the negative effects of child marriage. Fifth, open opportunities for adolescents to develop their potential, so that the gap in the child marriage can be minimized. To realize these steps, the government, parents and the community must work together in accordance with their respective capacities.
\end{abstract}

Keywords: Regulation, Prevention, Child Marriage, Marriage Law

\begin{abstract}
Abstrak
Merujuk pada data Badan Pusat Statistik Tahun 2017, tingkat perkawinan anak di Indonesia masih menunjukkan angka yang tinggi. Dari hasil sebaran 21 provinsi dari 34 provinsi di seluruh wilayah Indonesia diketahui kuantitas perkawinan anak mencapai angka $61 \%$ (enam puluh satu persen). Angka ini sangat mengkhawatirkan bila tidak segera mendapatkan perhatian semua jajaran pengambil kebijakan maupun praktisi dan akademisi hukum di Indonesia. Persoalan ini masih saja mencuat kepermukaan ibarat mata rantai yang saling berkaitan dan sulit untuk diputuskan. Meskipun produk hukum yang terkait dengan perkawinan pada hakikatnya sudah cukup memberikan aturan dan batasan usia perkawinan, namun perlu penguatan di jajaran aplikasi dan implementasi di tengah-tengah masyarakat. Melalui tulisan artikel ini akan diuraikan solusi yang tepat untuk penguatan regulasi dalam mencegah dan menanggulangi praktik perkawinan anak di Indonesia dengan menggunakan pendekatan integrasi-interkoneksi, yang tidak hanya cukup dalam ranah pemikiran melainkan juga menyentuh aspek praktis dan aplikasinya.
\end{abstract}

Kata Kunci: Regulasi, Perkawinan Anak, Pencegahan, Penaggulangan.

* Dosen Fakultas Syariah Universitas Islam Negeri (UIN) Raden Intan Lampung. 
ADHKI: Journal of Islamic Family Law

\section{Pendahuluan}

Perkawinan usia anak adalah perkawinan yang dilakukan oleh pasangan sebelum mereka berusia 18 tahun. Seorang anak yang menikah diusia di bawah 18 tahun sangat rentan terjadinya konflik dalam rumah tangga. Karena mereka umumnya belum siap untuk membina rumah tangga, dan belum bijak dalam memutuskan segala sesuatunya yang dipandang penting dalam kehidupannya. Selain itu, mereka cenderung memiliki kondisi fisik, mental, dan emosional yang belum stabil dan mapan, sehingga anak tumbuh secara tidak alamiah karena ia dipaksa dan terpaksa mamasuki masa dewasa diusia dini, dan dihadapkan pada tanggungjawab yang besar. ${ }^{1}$ Usia di bawah 18 tahun masih membutuhkan bimbingan dan pengawasan orangtua, kelanjutan pendidikan, dan semua hak dan perlindungan lainnya. Dalam kasus tertentu, orang tua menikahkan anak perempuannya di usia dini karena diharapkan dapat menopang kelangsungan perekonomian keluarga. Mereka percaya bahwa cara ini merupakan solusi terbaik untuk keluar dari himpitan ekonomi. ${ }^{2}$

Pembahasan seputar perkawinan anak atau pernikahan dini sudah sering diperbincangkan di kalangan praktisi dan akademisi, baik di dalam maupun di luar negeri. Persoalan ini masih saja mencuat kepermukaan ibarat mata rantai yang sulit untuk diputuskan. Hal ini dapat dibuktikan dengan angka yang dilaporkan Badan Pusat Statistik, bahwa perkawinan anak di Indonesia masih menempati posisi tertinggi di kawasan Asia Timur dan Pasifik dalam tiga dekade terakhir.

Berdasarkan data yang ada pada Badan Pusat Statistik Tahun 2017, diketahui bahwa sebaran angka perkawinan anak di atas $10 \%$ merata berada di 23 Provinsi di Indonesia, dan ini mengindikasikan bahwa $67 \%$ wilayah provinsi di Indonesia darurat perkawinan anak dan praktik perkawinan ini ditemui hampir diseluruh wilayah Provinsi di Indonesia. ${ }^{3}$ Tahun 2017 ternyata upaya mengurangi angka perkawinan anak mengalami kegagalan dibandingkan tahun 2015. Kondisi ini tentu dapat membahayakan jika tidak segera ditanggulangi, karena angka perkawinan anak tidak mengalami penurunan yang signifikan.

Meskipun secara yuridis formal, regulasi yang mengatur usia perkawinan di Indonesia sudah cukup memadai, namun penerapan aturan hukum tersebut masih perlu dilakukan pembenahan dan penguatan, sehingga benar-benar mengakar ke semua lapisan masyarakat Indonesia. Praktisi dan akademisi hukum di Indonesia harus terus menggiatkan dan menyuarakan penghapusan praktik perkawinan anak dan praktik pemaksaan perkawinan terhadap anak.

Sejauh ini belum ada penerapan sanksi yang tegas bagi pelaku perkawinan anak dan orang tua yang memaksa anak di bawah umur untuk

\footnotetext{
${ }^{1}$ FA. Kurniasari, "Implementasi Konvensi Hak Anak Dalam Kebijakan Kabupaten GunungKidul Untuk Mengurangi Jumlah Pernikahan Anak, (Studi Kasus Tahun 2013-2017), 5

2 BPS, Analisis Data Perkawinan Usia. "di Indonesia." Jakarta: Badan Pusat Statistik 2016, 5

3 http://www.koalisiperempuan.or.id/wp-content/uploads/2017/12/Lampiran-I-rilisperkawinan-anak-18-des-17-2.pdf, diakses tanggal 9 Maret 2019
} 
melangsungkan perkawinan. Bahkan lembaga dispensasi kawin bagi anak di bawah umur melalui institusi peradilan masih menyediakan celah untuk berlanjutnya praktik perkawinan anak. Tulisan ini berupaya memberikan solusi dalam penguatan regulasi sebagai upaya mencegah dan menanggulangi praktik perkawinan usia anak khususnya di Indonesia. Pembahasan dalam tulisan ini dilakukan secara integral, sehingga mata rantai nilai-nilai kemanusiaan dan ke Tuhanan tidak terputus.

\section{Metode Penelitian}

Penelitian ini adalah jenis penelitian pustaka dengan meneliti aspek normatif yang mengkaji aspek hukum tertulis dengan menganalisis konsistensi antara peraturan perkawinan yang ada di Indonesia. Data penelitian diperoleh dari Kemudian memaparkannya secara rinci dan sistematis beberapa aspek yang dijadikan objek kajian. Pendekatan yang digunakan adalah Pendekatan integratif-interkonektif, yakni pendekatan yang berupaya saling menghargai: keilmuan umum dan agama sadar akan keterbatasan masing-masing dalam memecahkan problem yang ada, sehingga melahirkan kerjasama sekurangkurangnya memahami pendekatan dan metode berfikir antara kedua bidang kajian/keilmuan tersebut. ${ }^{4}$ Dalam pendekatan secara integratif menginginkan terjadinya hubungan atau sinkronisasi antara bidang keilmuan, karena setiap bidang ilmu tidak mungkin untuk berdiri sendiri. Menurut Khoirudddin Nasution, sinkronisasi ini dapat dimunculkan secara integrasi, interdisipliner, dan interkonektif. ${ }^{5}$ Dengan pendekatan ini akan dimunculkan solusi penguatan regulasi dalam mencegah dan menanggulangi perkawinan usia anak di Indonesia.

\section{Perkawinan Anak dalam Hukum Islam}

Peraturan perundang-undangan tentang perkawinan di setiap negara memiliki batasan yang berbeda-beda tentang usia boleh dan tidak boleh untuk menikah, dikarenakan setiap negara memiliki alasan dan politik hukum yang berbeda-beda yang disesuaikan dengan kondisi dan cultur negaranya masingmasing, tidak terkecuali pula di negara-negara Islam.

Hukum Islam tidak menetapkan batas usia minimal dan maksimal untuk menikah, tetapi yang diatur adalah usia baligh sebagai ukuran untuk siap menerima pembebanan hukum taklifi. Demikian pula para ulama terdahulu tidak membahas batasan usia minimum, tetapi lebih banyak mengkaji tentang hukum mengawinkan anak yang masih belia. Perkawinan usia anak dalam fiqh

${ }^{4}$ Amin Abdullah, Desain Pengembangan Akademik IAIN menuju UIN Sunan Kalijaga, dari pendekatan Dikotomis-Atomistis ke arah Integratif-Interdisiplinary" dalam Zainal Abidin Bagir: "Integrasi Ilmu dan Agama, (Yogyakarta Pustaka Pelajar, 2008), h. 242.

5 Khoiruddin Nasution, Paradigma Implementasi Pendekatan Integrasi-Interkoneksi dalam Kajian Pendidikan Islam, Materi Diskusi Pada Seminar Nasional, PPs UIN Sunan Kalijaga Yogyakarta, Tanggal 15-16 Oktber 2014. 
diistilahkan dengan nikah al-shaghir/shaghirah atau al-zawwaj/al-mubakkir, yang dimaknai dengan anak kecil. Adapun yang dimaksud oleh para ulama adalah anak laki-laki dan anak perempuan yang belum baligh. ${ }^{6}$

Baligh adalah suatu periode memasuki usia dewasa yang ditandai dengan mengeluarkan air mani bagi laki-laki, dan telah haid bagi perempuan. Tentu setiap orang tidak memiliki kesamaan kapan dan pada usia berapa ia memasuki periode ini, misalnya ada anak perempuan yang mulai mengalami masa haid di usia 9 tahun, ada yang mulai di usia 16 tahun dan seterusnya, karena hal ini dipengaruhi kematangan biologis yang berbeda-beda. Begitu pula dengan batas maksimalnya tidak terdapat keseragaman.

Imam Abu Hanifah batas akhir usia anak adalah setelah seseorang mencapai usia 18 tahun bagi laki-laki dan usia 17 tahun bagi perempuan. Sedangkan menurut jumhur ulama, yaitu apabila seseorang telah mencapai usia 15 tahun baik laki-laki maupun perempuan.

Wahbah al-Zuhailiy menjelaskan baligh untuk menikah dengan kritria sampainya seseorang pada ambang batas usia untuk melakssanakan perkawinan, di mana menurutnya usia nikah aaah sampainya seorang laki-laki pada masa ihtilam (mimpi), yaitu ketika ia telah menginjak usia baligh dan telah dibebani dengan hukum taklifi, dan hukum-hukum wadh'i lainnya. Jika dikalkulasikan maka itu terjadi diusia lebih kurang 15 tahun menurut Imam Syafi'i dan Ahmad. ${ }^{7}$

$$
\text { و قال الشافعية و الحنابلة أن البلو غ بالسن يتحقق بخمس عشرة سنة في الغلام و الحارية }
$$

Artinya: Anak laki-laki dan anak perempuan dipandang telah baligh manakala sudah mencapai usia 15 tahun. ${ }^{8}$

Al-Qur'an memberikan tuntunan bahwa seseorang yang akan melangsungkan penikahan harus memiliki kemampuan dan kesiapan lahir dan batin. Allah Swt berfirman dalam al-Qur'an sebagai berikut:

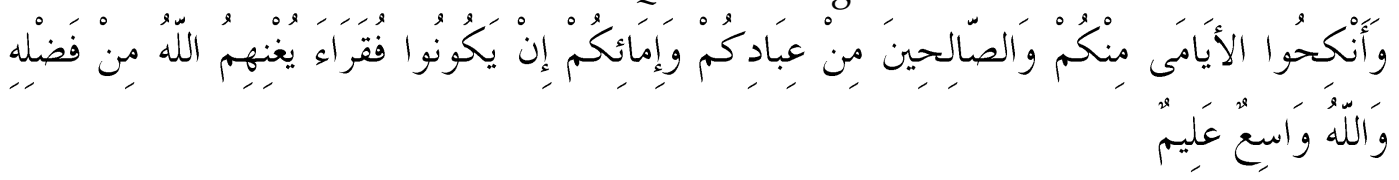

Artinya : Dan kawinkanlah orang-orang yang sendirian di antara kamu, dan orangorang yang layak (berkawin) dari hamba-hamba sahayamu yang lelaki dan hamba-hamba sahayamu yang perempuan. Jika mereka miskin Allah akan memampukan mereka dengan kurnia-Nya. Dan Allah Maha luas (pemberian-Nya) lagi Maha Mengetahui. ${ }^{9}$

Pada ayat lain, yaitu (QS: Al-Nisa' [4]: 6) juga dijelaskan :

${ }^{6}$ Hussein Muhammad, Figh Perempuan (Refleksi Kiai atas Wacana Agama dan Gender), (Yogyakarta, LkiS, 2007), 90

${ }^{7}$ Wahbah Al-Zuhailly, Tafsir al Munir, Juz III, (Damaskus: Dar al-Fikr. 2005), 258

8 Muhammad Jawad Mughniyyah, al Ahwal al Syakhsiyyah (Beirut : Dar al 'Ilmi lil Malayain, tt). 16

${ }^{9}$ QS: Al-Nur: 32 


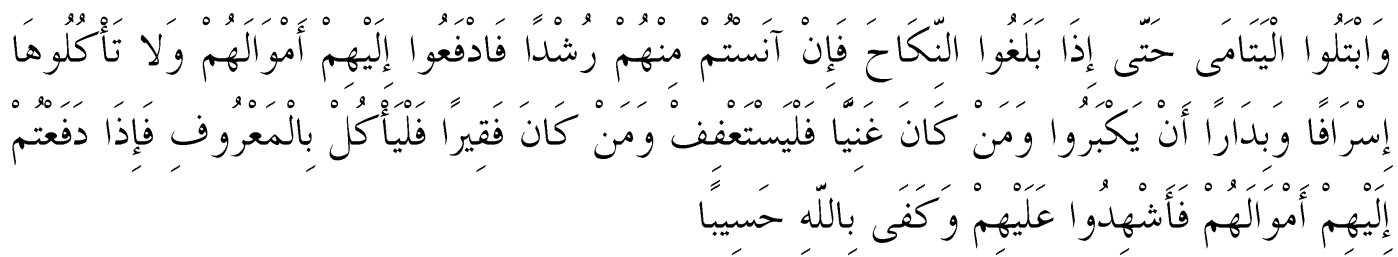

Artinya : Dan ujilah anak yatim itu sampai mereka cukup umur untuk kawin. Kemudian jika menurut pendapatmu mereka telah cerdas (pandai memelihara harta), maka serahkanlah kepada mereka harta-hartanya. Dan janganlah kamu makan harta anak yatim lebih dari batas kepatutan dan (janganlah kamu) tergesa-gesa (membelanjakannya) sebelum mereka dewasa. Barang siapa (di antara pemelihara itu) mampu, maka hendaklah ia menahan diri (dari memakan harta anak yatim itu) dan barang siapa miskin, maka bolehlah ia makan harta itu menurut yang patut. Kemudian apabila kamu menyerahkan harta kepada mereka, maka hendaklah kamu adakan saksi-saksi (tentang penyerahan itu) bagi mereka. Dan cukuplah Allah sebagai Pengawas (atas persaksian itu). ${ }^{10}$

Dijelaskan pula dalam Hadis nabi Muhammad Saw, berikut:

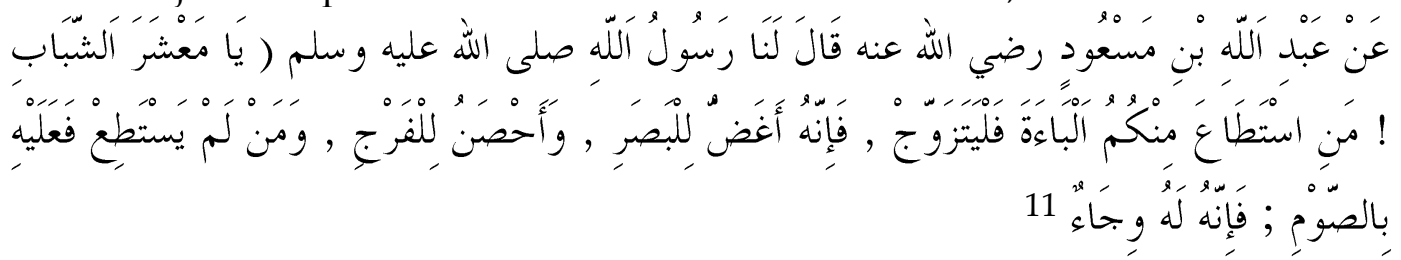

Artinya : Abdullah Ibnu Mas'ud Radliyallahu'anhu berkata: Rasulullah Saw bersabda pada kami: "Hai para pemuda, barangsiapa diantara kamu telah mampu untuk menikah, maka nikahlah, karena hal itu dapat menundukkan pandanganmu dan memelihara kemaluanmu. Barangsiapa belum kuasa, maka hendaklah ia berpuasa, karena puasa dapat mengendalikanmu.

Rasulullah SAW mensyaratkan adanya "kemampuan" yang dapat dimaknai dengan kesiapan fisik maupun mental atau kesiapan lahir dan batin calon pasangan suami isteri untuk mengemban tanggungjawab dan tugas rumah tangga, dan kemampuan ini tentunya hanya dapat dijalankan oleh orang yang telah dewasa secara lahir dan batin.

Pemahaman yang integratif-interdisipliner diperlukan dalam memahami sendi dasar membina keluarga bahagia yang dilingkupi rasa kasih dan sayang. Tidak cukup hanya dipahami secara tekstual-monodisiplin semata yang hanya mengacu pada satu bidang kajian. Begitu juga dalam memahami nash-nash perkawinan perlu disoroti dengan berbagai aspek hukum yang relevan, di antaranya adalah dengan menggunakan pendekatan sosiologis-antropologis, di mana nash tersebut diturunkan dan diaplikasikan.

Ajaran Islam memang tidak melarang perkawinan usia anak (dini), tetapi juga tidak menganjurkan dan tidak mendukung terjadinya perkawinan usia anak, terlebih jika dilaksanakan tanpa mengindahkan dimensi mental, hak-hak

\footnotetext{
${ }^{10}$ QS: Al-Nisa': 6

${ }^{11}$ Muhammad bin Ismail bin Ibrahim ibn al Mughirah Al-Bukhari, Shahih al Bukhari, (Beirut: Dar al-Fikr, tt), 187
} 
terbaik anak, faktor fisik dan mental anak (terutama anak perempuan). Yang menjadi tujuan syara' adalah kematangan kedua belah pihak dalam membentuk sebuah rumah tangga, sehingga terwujud rumah tangga yang sakinah, mawaddah dan rahmah, dan melahirkan keturunan yang kuat dan sehat, bukan keturunan yang lemah.

Diturunkannya syariat Islam salah satunya adalah guna menjaga kesucian keturunan (hifz al-nasl) yang dilahirkan dari perkawinan yang sah. Untuk menghasilkan keturunan yang berkualitas diperlukan kesiapan jasmani dan rohani calon mempelai laki-laki dan perempuan dan kematangan usia dan fisik yang siap untuk melakukan prosesi reproduksi.

Ibnu Syubrumah berargumentasi bahwa anak laki-laki dan anak perempuan yang masih di bawah umur tidak dianjurkan untuk dinikahkan hingga mereka mencapai usia baligh, dan atas persetujuan yang bersangkutan. ${ }^{12}$

Usia yang dipandang layak untuk melangsungkan perkawinan menurut fatwa MUI adalah diukur dengan kecakapan berbuat dan menerima hak (Ahliatul ada' wa ahliyyatul wujub). ${ }^{13}$ Ahliyatul ada' merupakan sifat kecakapan melakukan tindakan hukum bagi seseorang yang dianggap sempurna mempertanggungjawabkan perbuatannya, baik perbuatan yang sesuai dengan hukum maupun yang tidak sesuai dengan hukum. Ahliyyatul wujub merupakan kecakapan menerima hak-hak yang menjadi haknya, dan belum cakap dibebani kewajiban dan tanggungjawab. Oleh karena itu perkawinan usia anak memang tidak disarankan mengingat seorang yang belum dewasa belum mampu mengelola harta dan belum mampu memikul kewajiban-kewajiban dalam kehidupan sebagai suami dan isteri.

\section{Regulasi Perkawinan Anak di Indonesia}

Seiring perkembangan ketatanegaraan Indonesia yang direalisasikan dengan adanya perubahan UUD 1945 (1999-2002), Indonesia telah mengupayakan penguatan terhadap jaminan dan perlindungan Hak Asasi Manusia yang dituangkan dalam beberapa pasal tentang jaminan hak asasi manusia, termasuk di dalamnya hak membentuk keluarga dan hak-hak anak, yang selanjutnya dijabarkan dalam peraturan perundang-undangan di Indonesia.

Perkawinan adalah hak dasar setiap warga negara yang secara konstitusional dituangkan dalam Pasal 28 B ayat (1) UUD 1945, dan dijabarkan juga dalam Undang-Undang tentang Hak Asasi Manusia. Banyak persoalan hukum yang terkait dengan bidang perkawinan di Indonesia, di antaranya adalah usia perkawinan dan perkawinan anak.

\footnotetext{
12 Hussein Muhammad, Figh Perempuan (Refleksi Kiai atas Wacana Aama dan Gender, (Yogyakarta: LkiS, 2007), 100

${ }^{13}$ Majelis Ulama Indonesia, Ijma' Ulama (Keputusan Ijtima' Ulama Komisi Fatwa se Indonesia III Tahun 2009), (Jakarta: Majelis Ulama Indonesia, 2009), 78
} 
Undang-Undang Perkawinan memberikan arahan yang jelas tentang batasan usia minimal untuk melangsungkan perkawinan, yaitu dalam Pasal 7 ayat (1), 19 tahun untuk laki-laki dan 16 tahun untuk perempuan. Adapun usia dewasa dalam Undang-Undang ini ditentukan 21 tahun. Artinya ketika seorang belum berusia 21 tahun maka untuk melangsungkan perkawinan harus izin orang tua. Manakala usianya belum cukup 16 tahun (perempuan) dan 19 tahun (laki-laki) maka orangtua yang bersangkutan harus melakukan langkah pendewasaan (handlichting) yang harus diajukan permohonan kepada pengadilan. Pendewasaan ini wajib dilakukan karena pasangan yang akan menikah belum memenuhi syarat usia minimum yang telah diatur dalam Undang-Undang Perkawinan.

Kategori anak dalam menurut Pasal 1 Undang-Undang Nomor 23 Tahun 2002 Tentang Perlindungan Anak, adalah seseorang yang belum mencapai usia 18 tahun. Undang-Undang Perlindungan anak juga menyinggung dalam salah satu pasalnya tentang pencegahan perkawinan di usia anak-anak. ${ }^{14}$ Jadi perkawinan anak dimaknai dengan perkawinan yang terjadi sebelum seseorang mencapai usia 18 tahun, yang mana secara fisik dan psykhis anak tersebut belum matang, dan belum mampu bertanggungjawab terhadap dirinya maupun pasangannya, terlebih terhadap anak yang dilahirkan dari perkawinan tersebut.

Terkait batas usia perkawinan, Mahkamah Konstitusi pada tanggal 13 Desember 2018 telah mengeluarkan Putusan Nomor 22/PUU-XV/2017 yang amar putusannya mengabulkan permohonan para pemohon untuk mengubah ketentuan Pasal 7 ayat (1) Undang-Undang Nomor 1 Tahun 1974 tentang Perkawinan, yang mengatur tentang batas usia minimum untuk menikah. Dalam putusan tersebut MK menyatakan bahwa Pasal 7 ayat (1) sepanjang frasa "usia 16 tahun" UU Nomor 1 Tahun 1974 tentang Perkawinan bertentangan dengan UUD 1945 dan tidak mempunyai kekuatan hukum mengikat, selanjutnya MK memerintahkan kepada DPR untuk merevisi UU Perkawinan tersebut dalam tenggang waktu 3 tahun kedepan, karena dinilai inkonstitusional. Jika dalam tenggang waktu tersebut belum dilakukan perubahan maka demi kepastian hukum dan mencegah diskriminasi, maka penentuan batas minimal usia perkawinan disesuaikan dengan usia anak yang telah dirumuskan dalam Undang-Undang Perlindungan anak, yaitu 18 tahun, tanpa membedakan jenis kelamin laki-laki dan perempuan.

Salah satu dasar pertimbangan filosofis putusan Mahkamah Konstitusi di atas adalah terkait dengan pertimbangan perlindungan bagi anak perempuan.

${ }^{14}$ Lihat Pasal 26 ayat (1) Undang-Undang Nomor 23 Tahun 2002 tentang Perlindungan anak, merumuskan: “Orangtua brkewajiban dan bertanggungjawab untuk: (a) mengasuh, memelihara, mendidik, dan melindungi anak; (b) menumbuhkembangkan anak sesuai dengan kemampuan, bakat, dan minatnya; dan (c) mencegah terjadinya perkawinan pada usia anak-anak. https://pih.kemlu.go.id/files/UUNo23tahun2003 PERLINDUNGANANAK.pdf, diakses tanggal 29 Maret 2019 
Sebagaimana dijelaskan dalam angka 4 huruf d UU Perkawinan yang secara eksplisit menyatakan menganut asas bahwa calon suami-isteri harus matang jiwa dan raganya untuk melangsungkan perkawinan, agar mampu mewujudkan tujuan perkawinan dengan baik tanpa harus berakhir dengan perceraian, serta dapat keturunan yang sehat jasmani dan rohaninya. Dengan pertimbangan inilah sehingga perkawinan anak diusia dini harus segera dicegah dengan merevisi peraturan perundang-undangan yang terkait dengan perkawinan.

Selanjutnya dikuatkan juga dalam Konsideran huruf (e) Konsideran Undang-Undang Nomor 52 Tahun 2009 Tentang Perkembangan Kependudukan dan Pembangunan Keluarga, huruf (e), yang mengamanatkan bahwa "dalam mewujudkan pertumbuhan penduduk yang seimbang dan keluarga yang berkualitas, dilakukan upaya pengendalian angka kelahiran dan penurunan angka kemtian, pengarahan mobilitas penduduk, pengembangan kualitas penduduk pada seluruh dimensinya, peningkatan ketahanan dan kesejahteraan keluarga, penyiapan dan pengaturan perkawinan serta kehamilan sehingga penduduk menjadi sumber daya manusia yang tangguh bagi pembangunan dan ketahanan nasional, serta mampu bersaing dengan bangsa lain, dan dapat menikmati hasil pembangunan secara adil dan mereta. ${ }^{15}$ Kebijakan pembangunan keluarga melalui pembinaan ketahanan dan kesejahteraan keluarga guna mendorong keluarga agar dapat melaksanakan fungsinya secara optimal, dengan cara meningkatkan kualitas remaja melalui pemberian akses informasi, pendidikan, konseling dan pelayanan tentang kehidupan berkeluarga.

\section{Penguatan Regulasi dalam Upaya Pencegahan Perkawinan Usia Anak}

Pencegahan perkawinan usia anak pada hakikatnya adalah upaya-upaya yang dapat dilakukan dalam rangka melarang dan menghindari terjadinya perkawinan pada usia anak guna menurunkan angka perkawinan pada usia anak, seperti: membuat kebijakan, program, kegiatan, aksi sosial serta upayaupaya lainnya yang melibatkan pemerintah pusat, pemerintah daerah, orang tua, anak, masyarakat, dan para pemangku kepentingan.

Tujuan dilakukannya pencegahan perkawinan anak adalah: (1) demi melindungi anak dan memenuhi hak-hak anak agar dapat hidup, tumbuh dan berkembang, serta berpartisipasi secara optimal sesuai dengan harkat dan martabatnya sebagai makhluk ciptaan Tuhan YME; (2) Menjadikan akan tumbuh berkualitas, berakhlak terpuji dan sejahtera lahir dan batin; (3) Meminimalisir terjadinya tindakan kekerasan terhadap perempuan dan anak; (3) Mewujudkan kualitas kesehatan ibu dan anak baik fisik maupun mentalnya, sehingga dapat menurunkan angka kematian ibu dan anak. Edukasi tentang kesehatan bagi perempuan dan anak mengenai penundaan pernikahan dan kehamilan usia muda harus digiatkan agar perempuan khususnya tidak buta dengan kesehatan reproduksi. Informasi terkait kesehatan reproduksi bagi para remaja sangat

${ }^{15}$ https://peraturan.bpk.go.id/, diakses tanggal 22 Juni 2019 
penting guna menghindari maraknya pernikahan usia anak. Oleh sebab itu, pemerintah, tenaga kesehatan, dan orang tua perlu menyampaikan hal mendasar yang berhubungan dengan norma dan informasi kesehatan reproduksi; (4) Mencegah anak-anak putus sekolah, sehingga kedepannya dapat diwujudkan anak Indonesia yang berpendidikan maju, dan tidak terbelakang. Terlebih bagi anak perempuan sangat tidak memungkinkan untuk melanjutkan studi pasca perkawinan karena berbagai faktor dan kesibukan terlebih setelah melahirkan, berbeda dengan anak laki-laki yang masih memngkinkan untuk melanjutkan studi setelah menikah; (5) untuk mewujudkan pertumbuhan penduduk yang seimbang dan keluarga yang berkualitas.

Sangat menarik untuk disimak Hasil Seminar Nasional Terkait Percepatan, Pencegahan, dan Penghapusan Perkawinan anak, pada tanggal 12 September 2017 di Jakarta, telah menghasilkan beberapa kesepakatan guna mendorong Pemerintah Pusat maupun Pemerintah Daerah untuk segera mengambil inisiatif sebagai berikut: (1) Percepatan pencegahan Perkawinan anak, yakni dengan jalan penguatan substansi hukum dengan merealisasikan perubahan atau penerbitan kebijakan yang terkait dengan perubahan UU Perkawinan Nomor 1 Tahun 1974, atau menerbitkan Perppu tentang Pencegahan dan Penghapusan Perkawinan Anak sampai ke daerah-daerah dan desa-desa. Serta mendorong penyusunan dan penerbitan rencana aksi nasional dan daerah. (2) Percepatan pencegahan melalui penguatan komitmen aparat dan pejabat layanan publik melalui sinergitas di semua lintas sektor, dan bidang, perencanaan dan pengalokasian anggaran, serta mengefektifkan lembaga yang diinisiasi oleh pemerintah, baik dalam hal pengawasan maupun evaluasinya di tingkat pemerintah. (3) Melibatkan masyarakat sipil dalam setiap aktifitas mulai dari perencanaan, pengimplementasian, sampai pada monitoring dan penilaian dan pertanggungjawaban. (4) Menguatkan aspek budaya dengan mentradisikan pada setiap keluarga untuk tidak menikahi anak pada usia dini, memprioritaskan pendidikan saat usia anak, menggunakan pendekatan secara persuasif dalam rangka mengingatkan orang tua agar tidak terlalu dini menikahkan anaknya, serta mendorong segenap pihak untuk berpartisipasi dala mencegah terjadinya perkawinan anak. (5) Memprioritaskan kepentingan anak yang lebih baik untuk masa depan anak. ${ }^{16}$

Pada hakikatnya Undang-Undang Perkawinan telah memberikan solusi dalam rangka meminimalisir terjadinya perkawinan anak, yakni membuka kesempatan bagi pihak yang berkepentingan untuk melakukan pencegahan perkawinan, terutama pencegahan terhadap perkawinan anak. Dalam Pasal 13 UU Perkawinan dituangkan bahwa : "Perkawinan dapat dicegah apabila ada orang yang tidak memenuhi syarat-syarat untuk melangsungkan pernikahan". Dan "Pencegahan perkawinan dapat dilaksanakan apabila salah satu pihak atau

${ }^{16} \mathrm{http}: / / w w w . k o a l i s i p e r e m p u a n . o r . i d / 2017 / 09 / 13 /$ rilis-percepatan-pencegahan-danpenghapusan-perkawinan-anak/, diakses tanggal 27 Maret 2018 
kedua-duanya ada yang tidak memenuhi persyaratan untuk melangsungkan perkawinan. Syarat batas usia yang dituangkan dalam UU Perkawinan perlu diperjelas kembali, agar perkawinan anak dapat dilakukan pencegahan oleh pihak terkait jika ada orang tua yang menikahkan anaknya di bawah usia tersebut. Tindakan pencegahan ini dapat dilakukan oleh pihak terkait, namun akan lebih efektif jika melibatkan aparat pemerintahan di desa masing-masing dengan bekerja sama bersama tokoh agama dan masyarakat setempat.

Di antara upaya yang dapat ditempuh dalam penguatan regulasi yang terkait dengan persoalan perkawinan anak di Indonesia adalah, Pertama, giat melakukan sosialisasi kepada segenap lapisan masyarakat, baik dengan menggunakan pendekatan keagamaan, pendidikan, budaya, maupun ekonomi. Kedua, melakukan konsolidasi dalam rangka menyatukan dan memperkuat hubungan antara pembuat kebijakan dengan tokoh agama, masyarakat dan praktisi hukum dan pendidikan untuk menuangkan pemikiran yang mendorong percepatan meminimalisir perkawinan anak di Indonesia. Ketiga, menciptakan sinergisitas antara tugas dan tanggungjawab para pemangku kepentingan mulai dari pemerintah, tokoh agama, tokoh masyarakat, Lembaga Swadaya Masyarakat, pelaku bisnis, dan segenap pihak yang langsung maupun tidak langsung melaksanakan kebijakan program, dan kegiatan yang terkait dengan pencegahan maupun penanggulangan perkawinan anak.

Selain itu langkah lainnya yang tidak kalah pentingnya adalah, Pertama, memperkuat ketahanan keluarga, seperti kemandirian ekonomi, baik sandang, pangan maupun papan, mereka harus dibekali dengan pengetahuan dan keterampilan sebagai modal dan kelangsungan hidup anggota keluarga. Semakin meningkat taraf kehidupan ekonomi dan tingkat pendidikan dan pengetahuan masyarakat, maka akan semakin kokoh posisi demand dan masyarakat akan semakin integratif. Keluarga adalah wahana pertama dalam membentuk karakter seseorang melalui komunikasi yang baik di antara sesama anggota keluarga. Harus dikikis habis stigma negatif bahwa orangtua merasa malu memilliki anak perempuan yang sudah baligh secara biologis tetapi belum menikah. Dan stigma bahwa menikahkan anak perempuan pada pihak yang mapan secara ekonomi dapat membantu meningkatkan ekonomi keluarga.

Kedua, harus dilakukan sosialisasi kepada masyarakat terkait bahaya yang ditimbulkan dari perkawinan tersebut dengan cara melibatkan tokoh masyarakat dan tokoh agama.

Dengan demikian dapat dipahami bahwa, perkawinan usia anak dapat diminimalisir dengan cara pemerintah harus membuat jaringan yang kuat yang melibatkan semua lapisan masyarakat dari semua lini. Selain itu perlu dilakukan berbagai upaya dan langkah-langkah yang preventif, baik oleh para pengambil kebijakan, pelaksana kebijakan, akademisi, praktisi, maupun seluruh lapisan masyarakat. Penguatan terhadap jaminan dan perlindungan HAM dengan sendirinya mengharuskan bangsa Indonesia segera menyesuaikan produk 
hukum masa lalu yang dipandang tidak relevan lagi agar disesuaikan dengan perkembangan hukum dan perkembangan masyarakat Indonesia saat ini.

\section{Penguatan Regulasi dalam Upaya Penanggulangan Perkawinan Usia Anak}

Upaya mengimplementasikan regulasi yang terkait dengan persoalan anak (termasuk juga di dalamnya persoalan perkawinan anak), semestinya dilakukan dengan menggunakan pendekatan integrasi interkoneksi. Semisal dengan mengkaji persoalan ini dalam kacamata pendekatan integrasi tidak hanya berbasis kepada aspek hukum keluarga melainkan mengintegsikan pada aspek ketahanan ekonomi, politik, dan budaya. Aspek kajian keilmuan ini merupakan satu kesatan yang dapat dijadikan sebagai pisau analisis dalam mencegah maupun menanggulangi persoalan perkawinan anak di Indonesia.

Amin Abdullah, mengulas dalam artikelnya bahwa hubungan antara ilmu dan agama tidak dibatasi dinding tebal yang tidak mungkin untuk dikomunikasikan, yang terpisah sedemikian ketat dan kaku, dan masih terlihat garis pembatas antara disiplin ilmu dan agama. Sudah saatnya antar bidang disiplin ilmu tersebut saling membuka diriuntuk berkomunikasi dan menerima masukan dari disiplin ilmu di luar bidangnya. Hubungan ini yang dikenal dengan sebutan interkoneksi, yakni hubungan saling menembus yang bercorak klarifikatif, afirmatif, saling koreksi dan klarifikasi, dan senantiasa melakukan pembaruan-pembaruan. ${ }^{17}$

Terjadinya Perkawinan usia anak dipengaruhi oleh berbagai faktor, di antaranya faktor sosial, budaya, ekonomi, pendidikan. Faktor rendahnya pendidikan juga sangat berpengaruh terhadap terjadinya perkawinan usia anak. Anak yang memiliki tingkat pendidikan yang rendah cenderung menikah diusia yang muda, karena dikhawatirkan akan menjadi beban bagi orangtuanya, sehingga pernikahan usia anak menjadi pilihan dan solusi bagi mereka yang putus sekolah. Meskipun sesungguhnya perkawinan ini tidak semuanya memutus mata rantai kemiskinan, bahkan akan menjadi beban yang berkelanjutan jika perkawinan tersebut putus dengan perceraian, karena pada umumnya anak perempuan yang diceraikan suaminya akan kembali lagi kerumah orang tuanya.

Selain itu adanya stigma masyarakat yang negatif tentang pernikahan setelah melewati masa pubertas yang dipandang sebagai hal yang memalukan bagi keluarga juga menjadi faktor terjadinya pernikahan usia anak.

Pendekatan yang dapat digunakan dalam mencegah terjadinya praktik perkawinan di usia anak di antaranya dengan pendekatan keagamaan, budaya, pendidikan, dan kesehatan, dengan melibatkan setiap lini dalam masyarakat,

17 Amin Abdullah, menjabarkan dalam tulisannya terkait "Agama, Ilmu, dan Budaya: Kontribusi Paradigma Integrasi-Interkoneksi Ilmu Dalam Menghadapi Isu-Isu Islamic Studies Kontemporer, di unggah melalui http://pps.uin-suka.ac.id, diakses tanggal 15 Juni 2019 
yaitu Keluarga, pemerintah, pihak yang berkompeten dalam pengambilan kebijakan, Para praktisi dan penegak hukum.

Penegakan hukum terhadap Peraturan perundang-undangan di Indonesia dalam rangka Penguatan regulasi perlu segera ditindaklanjuti. Langkah-langkah yang harus dilakukan adalah: Pertama, perlu melibatkan institusi peradilan dalam rangka menaikkan batas usia untuk mendapatkan dispensasi perkawinan. Dasar pertimbangan putusan hakim harus mencerminkan asas kemanfaatan, yang tidak hanya memberikan manfaat bagi pihak yang mengajukan permohonan dispensasi, tetapi juga bermanfaat untuk pembaruan hukum di Indonesia.

Hal yang mendasari pemberian dispensasi perkawinan oleh pengadilan agama dilatarbelakangi oleh berbagai faktor, di antaranya adalah: (1) hamil di luar nikah; (2) faktor ekonomi, dan (3) rendahnya pendidikan. Dikabulkannya dispensasi kawin oleh Pengadilan Agama di Indonesia sebagian besar memang didasari pada pertimbangan karena calon mempelai perempuan telah hamil di luar nikah. ${ }^{18}$ Apabila ada dua bahaya (mafsadat) yang akan terjadi dalam sebuah peristiwa, maka menghindari bahaya yang lebih besar diprioritaskan dari bahaya yang lebih kecil, sesuai dengan kaidah fiqh yang memberikan tuntunan bahwa apabila ada dua mafsadat yang saling bertentangan maka hendaklah dihindari bahaya yang lebih besar dengan mendahulukan bahwa yang lebih ringan.

\section{Penutup}

Persoalan pernikahan usia anak adalah masalah bersama yang harus ditanggulangi bersama oleh segenap praktisi hukum dan stakeholder, serta pemerintah. Dalam pengambilan kebijakan, pemerintah harus lebih berperan dalam melahirkan kebijakan yang efisien dan efektif sehingga dapat diimplementasikan dan dievaluasi secara konkrit ditengah-tengah masyarakat.

Dalam menguatkan regulasi tentang perkawinan di usia anak diperlukan berbagai upaya dan pendekatan yang integratif dan holistik. Karena persoalan ini tidak dapat hanya dianalisis dari satu sisi saja, melainkan harus dikaji dengan berbagai aspek dan pendekatan keilmuan yang integratif. Pemangku kebijakan perlu mengatur secara tegas dan jelas batas usia anak yang seragam di antara semua peraturan perundang-undangan di Indonesia yang terkait dengan anak. Namun persoalan ini tidak hanya dilihat dari sisi hukum dan peraturan perundang-undangan saja, namun harus dikaji dari aspek ekonomi, sosial, budaya, dan politik. Selain itu perlu melibatkan pihak-pihak terkait, seperti pengambil kebijakan, praktisi hukum, tokoh agama, tokoh pendidikan, pemuka masyarakat dan adat, orang tua dan praktisi kesehatan, yang saling bersinergis dan berkonsolidasi bersama-sama untuk mencegah dan menanggulangi

${ }^{18}$ Panjaitan, Hendripal. "Pelaksanaan Pemberian Dispensasi Perkawinan Di Pengadilan Agama Rantau Prapat Ditinjau Dari Undang-Undang 1974 Dan Hukum Islam." Prosiding Seminar Nasional Era Industri (SNEI) 4.0. Vol. 1. No. 1. 2018..469 
perkawinan di usia anak. Pemahaman yang integratif-interdisipliner diperlukan dalam memahami sendi dasar membina keluarga.

\section{Daftar Pustaka}

Amin Abdullah, Desain Pengembangan Akademik IAIN menuju UIN Sunan Kalijaga, dari pendekatan Dikotomis-Atomistis ke arah Integratif-Interdisiplinary" dalam Zainal Abidin Bagir: "Integrasi Ilmu dan Agama, Yogyakarta Pustaka Pelajar, 2008

Amin Abdullah, menjabarkan dalam tulisannya terkait "Agama, Ilmu, dan Budaya: Kontribusi Paradigma Integrasi-Interkoneksi Ilmu Dalam Menghadapi Isu-Isu Islamic Studies Kontemporer, di unggah melalui ; http://pps.uin-suka.ac.id

BPS, Analisis Data Perkawinan Usia. "di Indonesia." Jakarta: Badan Pusat Statistik, 2016

FA. Kurniasari, "Implementasi Konvensi Hak Anak Dalam Kebijakan Kabupaten GunungKidul Untuk Mengurangi Jumlah Pernikahan Anak, (Studi Kasus Tahun 2013-2017

Hussein Muhammad, Figh Perempuan (Refleksi Kiai atas Wacana Agama dan Gender), Yogyakarta, LkiS, 2007

Khoiruddin Nasution, Paradigma Implementasi Pendekatan Integrasi-Interkoneksi dalam Kajian Pendidikan Islam, Materi Diskusi Pada Seminar Nasional, PPs UIN Sunan Kalijaga Yogyakarta, Tanggal 15-16 Oktber 2014

Muhammad Jawad Mughniyyah, al Ahwal al Syakhsiyyah, Beirut : Dar al 'Ilmi lil Malayain, $\mathrm{tt}$

Muhammad bin Ismail bin Ibrahim ibn al Mughirah Al-Bukhari, Shahih al Bukhari, (Beirut: Dar al-Fikr, tt),

Majelis Ulama Indonesia, Ijma' Ulama (Keputusan Ijtima' Ulama Komisi Fatwa se Indonesia III Tahun 2009), Jakarta: Majelis Ulama Indonesia, 2009

Panjaitan, Hendripal. "Pelaksanaan Pemberian Dispensasi Perkawinan Di Pengadilan Agama Rantau Prapat Ditinjau Dari Undang-Undang 1974 Dan Hukum Islam." Prosiding Seminar Nasional Era Industri (SNEI) 4.0. Vol. 1. No. 1. 2018

Wahbah Al-Zuhailly, Tafsir al Munir, Juz III, (Damaskus: Dar al-Fikr. 2005

http://www.koalisiperempuan.or.id/wp-content/uploads/2017.

https://peraturan.bpk.go.id/,

http://www.koalisiperempuan.or.id/2017/09/13 